Derek C. Jones Takao Kato

Panu Kalmi

Mikko Mäkinen

Financial Participation

in Finland:

\title{
Incidence and Determinants
}


Derek C. Jones - Panu Kalmi - Takao Kato - Mikko Mäkinen

\section{Financial Participation in Finland: Incidence and Determinants}

Department of Economics

December

2010 
AALTO-YLIOPISTON KAUPPAKORKEAKOULU

AALTO UNIVERSITY SCHOOL OF ECONOMICS

PL 00076

FI-00101 HELSINKI

FINLAND

Derek C. Jones, Panu Kalmi, Takao Kato, Mikko Mäkinen and Aalto University School of Economics

ISSN 1235-5674

(Electronic working paper)

ISBN 978-952-60-1066-3

Aalto University School of Economics -

Aalto-Print 2010 


\title{
FINANCIAL PARTICIPATION IN FINLAND: INCIDENCE AND DETERMINANTS
}

\author{
Derek C. Jones*, Panu Kalmi**, Takao Kato*** and Mikko Mäkinen**
}

\begin{abstract}
We provide the first comprehensive analysis of financial participation in Finnish manufacturing companies. Compared to many developed economies, the incidence of profit sharing in Finland is found to be relatively high. Cash-based profitsharing (CPS) schemes are the most commonly used method of financial participation, and around $40 \%$ of manufacturing companies had them in 2005. Share-based schemes and personnel funds are much less common. Moreover, CPS schemes were growing fast in the early 2000s, while the number of other forms of financial participation had stagnated. In analyzing the determinants of financial participation, stakeholder ownership stands out. Firms that are owned by the state or co-operatives have over a $90 \%$ likelihood of having financial participation schemes, whereas the likelihood for other firms is only around $40 \%$. Firms mainly owned by management are less likely to offer financial participation. The evidence of complementarities with other management practices is fairly weak, although there is some evidence that higher levels of workplace training and higher computer use are associated with financial participation.
\end{abstract}

* Dept. of Economics, Hamilton College, Clinton, NY 13323, djones@hamilton.edu;

** Dept. of Economics, Aalto University, School of Economics, PO Box 1210, 00101

Helsinki, Finland and HECER, panu.kalmi@hse.fi and mikko.makinen@hse.fi . Kalmi is the corresponding author.

*** Dept. of Economics, Colgate University, Clinton, NY 13346, kato@mail.colgate.edu

We are grateful to the Academy of Finland (Grants 206027 and 120234) and the Finnish Work Environment Fund (Grants 103313 and 108708) for financial support, and to Antti Kauhanen for useful comments. 


\section{Introduction}

In this paper we investigate the incidence and evolution of financial participation of employees in Finnish manufacturing companies. We define financial participation consisting of broad-based profit- or equity-sharing (including share ownership and stock options) schemes (Poutsma and de Nijs 2003). Earlier studies on Finland have focused on more limited sets of financial participation practices (e.g. Piekkola 2005; Jones et al. 2006; Kauhanen and Piekkola 2006; Sweins et al. 2009). By assembling new and wideranging data on financial participation practices in Finnish manufacturing companies, we undertake the most comprehensive evaluation of the prevalence and determinants of financial participation for Finland to date. From earlier studies we know that performance-related pay (PRP) had become common in Finnish companies since the 1990s. One contribution of this study is to evaluate to what extent these PRP schemes can be regarded as financial participation. Another contribution is to assess the significance of direct employee share ownership in Finnish companies. Alongside with these practices, we also assess the role of broad-based stock options and personnel funds. Our data also allow us to look at the dynamics of financial participation during the period $2002-2005$.

The second goal of our paper is to analyze statistically the determinants of financial participation. Our new survey data enable us to introduce a number of control variables that have been regarded as important in earlier literature. These include company size, union density, various complementarities, for instance with employee participation (BenNer and Jones 1995), use of technology (Bresnahan et al. 2002) and other advanced management practices (Bloom and Van Reenen 2007). Perotin and Robinson (2003) 
report that the previous literature on the determinants of financial participation has produced contradictory results, and there is no consensus on the sign of even the most basic variables, such as company size or union status. Apart from differences in samples (e.g. some studies focus on listed firms only while others look only at manufacturing etc.), the differences in results are likely to reflect differences in institutional environment. Thus one of our main tasks in this paper is to give a detailed account on the institutional environment that facilitates our understanding on the interpretation of regression coefficients. Following Poutsma and de Nijs (2003), we focus on the relationship between financial participation on the one hand and corporate governance, employee participation and management practices on the other hand.

Further, we make a clear contribution to the literature by introducing several new corporate governance variables. We focus especially on the role of the identity of the owners. Perhaps our most novel contribution comes from our analysis of the role of stakeholder ownership as a determinant of financial participation. We are able to identify a variety of ownership structures from our sample: firms that involve a significant degree of stakeholder (state or co-operative) ownership, family ownership, foreign ownership, and managerial ownership.

The paper is structured as follows. Section 1 gives an overview of the types of financial participation that are present in Finland. Section 2 describes the institutional environment, focusing on industrial relations and corporate governance. Section 3 extends this discussion by presenting the empirically testable hypothesis. Section 4 presents our data, and describes the evolution and incidence of financial participation in 
Finland. Section 5 presents the results from our statistical analysis, and section 6 concludes.

\section{Financial participation in Finland}

In Finland there exist several different types of financial participation. The only form of financial participation that is subject to collective bargaining between employers and employees and that is supported by specific legislation is personnel funds, which is a form of deferred profit-sharing. The other well known type is stock options that became very common in listed companies during the 1990s (Jones et al. 2006). Performancerelated pay also increased rapidly during the 1990s (Piekkola 2005), but it has been unclear to what extent PRP represents financial participation. Also, there has been very little information on the use of direct share ownership in Finnish companies.

The definition of financial participation as used in this paper draws on earlier literature, notably Poutsma and de Nijs (2003) and Perotin and Robinson (2003). First, we require that the schemes are broad-based, i.e. they involve a broader group of employees than just managers or selected key employees. More specifically, we require that at least $50 \%$ of employees are actually covered by the scheme (and not just eligible). Second, the two main types of financial participation are share schemes (including stock options) and profit-sharing. We regard the scheme to be a profit-sharing scheme, if profitability is among the criteria at which employees are compensated. These criteria mostly gain relevance when we look at the PRP schemes (discussed more below).

Personnel funds is a Finnish deferred profit-sharing scheme that is regulated under the Law on Personnel Funds from 1990 (subsequently amended several times). ${ }^{1}$ Personnel funds differ from all other schemes in the sense that they are tightly regulated

\footnotetext{
${ }^{1}$ For a closer description on personnel funds, see Sweins et al. (2009).
} 
and supervised by the Ministry of Labour. The main idea of the funds is that they receive payments (profit-shares) according to specified performance criteria. Profitability is the main criterion, and usually the only one, for these payments. The profit-shares are further invested to the capital markets. Often a large part of the investment is allocated to the stock of the sponsoring firm, thereby creating indirect employee share ownership.

The funds are established and administered by the employees. All employees must belong to the fund, even though top management may be excluded. Each employee has an account in the fund. The profit-shares are allocated to the fund according to specific criteria, which may be working hours, wage income, or equal sharing. An employee has to be a member in the fund for at least five years before being entitled to withdraw from the account, and then only at most $15 \%$ of the accumulated capital per annum. Upon departure, the money accumulated to the account is paid out during five years.

There are several tax advantages from using personnel funds. The employer can deduct the profit-sharing part in taxation. Funds are exempt from paying pension and social security payments on the profit-share. Employees receive $20 \%$ of the income from the fund tax-free and pay income tax on the rest. The personnel fund does not have to pay taxes on the return of its financial investment.

Personnel funds have been widely regarded as an equitable and inclusive form of financial participation. However, because of the deferred nature of profit-sharing, they have been regarded as less incentivizing than cash-based schemes, and they have been criticized as being rigid and bureaucratic. They are also difficult to apply in multinational settings. 
The funds gained popularity immediately after the legislation was enacted in 1990. In the first two years, 40 companies adopted them. However, few funds were established during the years of severe economic depression in Finland in 1992-1994. After the crisis, it became more popular to adopt stock options and other forms of PRP. However, during the 2000s personnel funds experienced a sort of comeback, especially in the service sector, as some of the largest Finnish firms (in postal services and banking) adopted them. At the end of 2008, there were 57 funds and close to 140.000 employees, which is almost $10 \%$ of the total employment of the salaried and wage employees in companies.

Stock options became popular in Finnish listed companies during the 1990s. The wave peaked in 2001 when around $85 \%$ of companies listed in the Helsinki Stock Exchange main list had stock options, and well over one-third of listed companies had broad-based stock options (Jones et al. 2006). However, the popularity of stock options started to wane after the bursting of the dot-com bubble. Jones et al. (2006) show that the increase of broad-based schemes correlated closely with the stock market index: options gained in popularity when the stock market was booming, and their popularity waned during the stock market bust in the early 2000 s.

Stock options are not backed by any specific legislation. Earlier the income from employee stock options was taxed at the rate of capital income which is lower than the wage income tax rate, but after 1994, and well before the boom of stock options, they have been taxed at the income tax rate. Stock options do not typically lead into employee share ownership, because the gain from exercising the stock options became taxable immediately when the options were exercised. Due to liquidity constraints and risk 
aversion, employees typically sold the shares immediately after the options were exercised. In several cases, there were secondary markets for options at which employees were able to trade their options directly, without subscribing company shares first.

The two remaining forms of financial participation in Finland are performancerelated-pay $(P R P)$ and direct share ownership. The Confederation of Finnish Industries (EK) has monitored the development of the pay systems in Finnish enterprises and from these reports it is evident that their popularity has increased since the 1990s. The reports also indicate that the rewards are typically based on company-level measures, and profitability has been the most common criteria for payment (EK 2006). These findings suggest that typical PRP schemes may be regarded as profit-sharing, and thereby as part of financial participation. Of direct share ownership schemes, very little is known, except that they are regarded as fairly common in human capital intensive industries, such as IT service firms.

There have been a small number of studies that have focused on the performance effects of Finnish financial participation schemes. These indicate positive effects from PRP (Piekkola 2005 and Jones et al. 2008a), whereas studies have indicated no significant performance effects either from stock options (Jones et al. 2010; Mäkinen 2010) or personnel funds (Kalmi and Sweins 2010).

\section{Institutional environment}

In this section we focus on the two issues of institutional environment that are believed to have an important bearing on the adoption of financial participation schemes (Poutsma and de Nijs 2003): the industrial relations regime and types of corporate governance. 
During recent decades the Finnish industrial relations has been described as hightrust, consensual and collaborative (Kalmi and Kauhanen 2008). The relations between employers and employees are regulated by co-decision arrangements codified in the Labour Law that give employees extensive consultation and co-decision rights. In the wage setting, the dominant features of Finnish industrial relations regime have been the high level of union density and high level of centralization in collective bargaining. ${ }^{2}$ The union density in Finnish manufacturing industries was in average over $80 \%$ in 2000 (Böckerman and Uusitalo 2006). Until recently, the wage bargaining took place in centralized negotiations where employer and employee representatives first agreed to general wage increases for all sectors. Only thereafter, the wage agreements were negotiated separately for different industries, but taking into consideration the centralized agreement. Once the negotiations have been concluded at the national and sectoral levels, the firms had to follow these general guidelines on wage levels and wage increases. They are allowed to pay higher wages than those agreed at higher levels, but not lower wages.

Trade unions are actively involved in the administration of personnel funds, where the fund chairmen are usually union shop stewards. This is because of the central role played by unions and shop stewards in employee representation in Finnish companies, but it is not based on legislation on funds.

The trade union and employer representatives have disputed the right of employee representation in PRP schemes. The current situation is that PRP schemes are set unilaterally by the management and employer representatives have not agreed to include PRP schemes into general wage agreements. However, these issues are often negotiated

\footnotetext{
${ }^{2}$ The Confederation of Finnish Industries announced in 2008 that they give up centralized bargaining and the wage negotiations will thereafter take place at the sectoral level. However, our data is up to 2005 that clearly still belonged to the era of centralized bargaining.
} 
between employee and employer representatives at the company level. The trade unions would like to bring these issues into the higher levels of collective bargaining but, so far, the employer organizations have resisted this initiative.

Employee stock options and employee share ownership are not negotiated in collective agreements. Trade unions have not shown much interest in negotiating over these issues. Their attitude towards share ownership is neutral and somewhat disinterested, and towards stock options is even negative. ${ }^{3}$

Turning to corporate governance issues, it has been argued that the Finnish corporate governance system has moved from a stakeholder-oriented model more towards shareholder-model (Tainio and Lilja, 2003). The move into greater dominance of shareholder goals has been interpreted to be a consequence of the increase of foreign ownership and of greater role for equity markets.

Until the 1990s, Finnish companies were typically owned by wealthy families or management of the company, with minority ownership stakes being held by the main bank of the company. The role of debt finance was pronounced. The situation changed in the 1990s when liberalization of foreign direct investment allowed foreign owners to enter the Finnish market. The number of firms in the Helsinki Stock Exchange main list increased from around 50 in 1987 to over 100 in 2000, and the trading volumes increased dramatically, increasing the importance of equity finance instead of debt finance (Jones et al. 2006). As a further move towards shareholder value orientation, shareholder rights were improved by legislation while creditor protection was weakened during the $1990 \mathrm{~s}$ (Hyytinen et al. 2003).

\footnotetext{
${ }^{3}$ Trade union attitudes towards different forms of financial participation are discussed in Kalmi (2005).
} 
Ownership structures have also changed fast during the past two decades. The liberalization of foreign ownership has meant that many Finnish firms have been bought by foreign capital. The banking crisis of the early 1990s eroded the ownership stakes held by banks, and bank ownership of shares is now insignificant. Though many state enterprises have been fully or partially privatized, the state has remained as an important shareholder in many enterprises. The Finnish Government Office has explicit corporate governance policies and one minister in the Cabinet has corporate governance among his responsibilities. ${ }^{4}$ Similar processes have been underway in the relatively large cooperative sector in Finland. Since the 1980s, some co-operative enterprises have been partially demutualized and transformed into joint-stock companies. However, usually the original owners of the co-operatives have retained a controlling majority voting stake. Family ownership remains important in many cases, even though some large family enterprises have been sold to outside shareholders.

\section{Conceptual framework}

In this section, we review our hypotheses related to the issues of corporate governance and industrial relations, building on the discussion of institutional framework presented in the previous section. We discuss some auxiliary hypothesis in the section where we present our data.

Corporate governance.

In the corporate governance debate, it is useful to relate the issues of ownership to the concept of shareholder value. The central problem in corporate governance has been how

\footnotetext{
${ }^{4}$ The corporate governance principles of the Finnish government can found in English from http://www.valtionomistus.fi/omistajapolitiikka ja ohjaus/omistajapolitiikka/en.jsp under the heading "ownership steering".
} 
to solve the principal-agent problem between shareholders and management, i.e. how to induce managers to make decision that maximize the return to equity investors (Shleifer and Vishny 1997). Another issue is that there may be owners who have broader objectives than maximizing returns on equity. This is often referred in the literature as stakeholder ownership (Tirole 2001). By stakeholders we mean parties that have a transaction relationship with the company other than supplying finance, including employees, suppliers, customers, and broader communities. Shleifer and Vishny (1997, p. 767) single out state and co-operative ownership as the two most important examples of stakeholder ownership. In some finance literature, the term 'stakeholder' has been used to denote blockholders or large investors owning more than a certain percentage of total voting shares (e.g. over 5\%). Our stakeholder owners are always blockholders, but we use the term 'stakeholder' only if blockholders have also another relationship with the company than being solely suppliers of finance.

These basic issues in corporate governance have so far not received sufficient attention in the literature of the determinants of financial participation. The notion of stakeholder participation has been used in the sense that by sharing the wealth generated at the workplace more broadly, employees (as stakeholders) would increase their effort levels and therefore getting them involved would also be beneficial to shareholders (Freeman et al. 2010). The underlying idea is that firms focusing narrowly on profitmaximization fail to provide financial participation to a degree that would be socially optimal (Blair 1995; Levine 1995). Often the debate is framed in the context of national systems: for instance, Japanese or German companies are viewed as more "stakeholderoriented", and the US and UK as more "shareholder-oriented". Discussing at the level of 
national systems, Poutsma and de Nijs (2003) argue that a general move towards shareholder value in European corporate governance and industrial relations system has been a contributing factor in the increase of financial participation schemes in Europe. As we noted above, such a shift towards more emphasis of shareholder value has occurred also in Finland.

Our contribution is to take this discussion from the macro-level to the micro-level and to see whether, within a given system, firms that are stakeholder-owned would be more or less inclined to use financial participation schemes. This is a hypothesis that has not been tested in previous research. ${ }^{5}$ The arguments of Blair (1995) and Levine (1995) would suggest that stakeholder-oriented firms might be more likely to adopt financial participation schemes, because they are under less immediate pressure to display shortterm profitability and therefore can afford sharing some of the profits or shareholder value with the employees. On the other hand, one might argue that financial participation schemes are more common among shareholder value maximizing firms, if the macrolevel argument of Poutsma and de Nijs (2003) can be extended to the micro-level.

We consider those companies that do not focus exclusively on profitmaximization as stakeholder-oriented. Following Shleifer and Vishny (1997), we regard companies owned either by the state or by co-operatives as the two most important categories of stakeholder ownership. In Finland, there are many companies where a significant degree of state ownership prevails. These companies aim to have a high level of profitability (and some of them are listed in the stock exchange), but profit is not their

\footnotetext{
${ }^{5}$ The potential importance of the identity of owners for economic behavior has been recognized in other areas. This is especially apparent in transition economics where a vast theoretical and empirical literature has appeared to investigate diverse issues surrounding the impact of firms with diverse forms of ownership. See for example, Estrin et al. (2009).
} 
only goal. Other more or less explicit goals include maintaining domestic production in strategically important industries, or protecting employment in economically distressed regions. A second example of stakeholder-oriented companies is firms that are owned by co-operatives. Finland has a vibrant co-operative sector (Jones and Kalmi, 2009), including strong consumer co-operatives and co-operative financial sector, but we concentrate here on co-operatives owned by agricultural producers. Such co-operatives are owned by the suppliers of their inputs in the fields of food production and forestry. ${ }^{6}$ Firms owned by the co-operatives also aim at profitability (and some of them are publicly traded), but they have also other goals, especially securing a market for the products of the members of the co-operatives.

Among other ownership configurations, we distinguish family firms and managerially-owned firms on the one hand, and foreign-owned and firms owned by domestic companies or investors on the other hand. In the first type of firms, the agency relationship between owners and management is reduced, because of the overlap between these two categories. ${ }^{7}$ This gives the managers of these firms strong incentives to maximize profits. However, it is possible that in the objective function of owners there are goals other than profit maximization. In the case of managerial ownership, managerowners are likely to value the status of ownership and enjoy the independence that comes from being in control of the company. In the case of family ownership, the owners are likely to attach more value to the continuity of the firm that would outsider owners. Both

\footnotetext{
${ }^{6}$ Co-operatives owned by agricultural producers should be clearly differentiated from co-operatives owned by their employees (worker co-operatives). The latter are themselves a form of financial participation. Worker co-operatives are virtually non-existent in the Finnish manufacturing sector, and therefore they are not discussed in this paper.

${ }^{7}$ Bloom and Van Reenen (2007) find that there is a substantial difference between firms that are familyowned but have outsider managers, and family-owned and family-managed firms. Our data do not allow us to make this distinction.
} 
of these considerations imply that managerial and family owners may be less likely to dilute their control and return rights in favour of either outsider investors or other stakeholders (Schulze et al. 2001). Therefore, we expect that the occurrence of financial participation may be less common in these firms.

\section{Industrial relations.}

Unionization has often been in central focus in many studies on the determinants of financial participation. The results have often been mixed, including Gregg and Machin (1988) and Pendleton (1997) finding mostly positive relationship for the UK but Pendleton (2006) reporting a non-significant relationship for the UK, Kruse (1996) and Ben-Ner et al. (2000) reporting mostly insignificant relationships for the US while Kruse et al. (2010) find a negative relationship, Jones and Kato (1993) finding a negative relationship for Japan and Jones and Pliskin (1997) reporting a negative relationship for Canada. Given the variety of the contexts that have been studied, this incoherence in results is perhaps understandable. In the Finnish context, we do not expect pronounced effects from unionization. One reason for this is that there is relatively little variation in union arrangements and densities, making it hard to detect a statistically significant relationship between unionization and financial participation. Also, in Finland collective arrangements agreed at the national or sectoral levels are binding even for non-union workplaces. ${ }^{8}$ For instance, in the case of Finland, it would definitely not make sense to adopt financial participation schemes as a union deference mechanism, even though this may have relevance in other contexts such as the U.S. (Kochan et al. 1986). In the Finnish case, we noted that union involvement has been more pronounced concerning

\footnotetext{
${ }^{8}$ Studies on the use and effects of high-performance work systems in Finland have found no effects from union membership (Kalmi and Kauhanen 2008; Kauhanen 2009).
} 
personnel funds, but otherwise there are no strong reasons a priori to expect a strong relationship between unionization and financial participation.

Another much studied relationship has been the relationship between financial participation and employee involvement or direct participation, including issues such as self-managed teams, quality circles, job rotation etc. Many authors argue that financial participation and employee involvement are complementary (Ben-Ner and Jones 1995; Levine 1995; Appelbaum et al. 2000). On the one hand, direct participation provides front-line workers (e.g., operators and front-line engineers in manufacturing and customer representatives and their immediate supervisors) with an opportunity to produce performance-enhancing local knowledge and share it with their peers and supervisors. Obviously if the interests of workers are not aligned with that of the firm, workers will have little incentive to put effort to produce such performance-enhancing local information and share it with management. The interest alignment between workers and the firm is fostered by financial participation. On the other hand, financial participation that rewards the performance of large groups, may provide meaningful incentives to improve work performance only when employees' job tasks are interrelated, as in teamwork.

Recent studies on work organization have suggested a wider range of complementarities. Higher levels of computerization and investments in human capital are found to be correlated with the decentralization of work organization (Bresnahan et al., 2002.) One reason human capital investments are related to financial participation is that employees can share in the return on these investments via financial participation. Also, the deferred nature of financial participation gives employees incentives to remain 
in the company until the investment has had a positive pay-off (Smith 1988; Robinson and Zhang 2005). Employee selection, appraisal, and performance feedback mechanisms are also crucial in choosing the best employees and developing their skills; they are likely to have complementarities with financial participation as well, as suggested by the literature on high-performance work systems (e.g. Becker and Gerhart 1996; Appelbaum et al. 2000). The work of Bloom and Van Reenen (2007) also suggests that there are complementarities between these 'advanced management practices' and employee incentives.

Given the strong priors about the complementarities between employee involvement and financial participation, it is somewhat surprising that the empirical results are rather mixed. Although some studies have found that employee direct participation is positively correlated with financial participation schemes (Pendleton 1997; Poutsma and Huijgen 1999; Kruse et al. 2010), many studies (including Kruse 1996; Festing et al. 1999; Ben-Ner et al. 2000; Poutsma et al. 2006; Pendleton 2006) tend to find insignificant or mixed relationships. Again, it is likely that the institutional contexts influence the results. Earlier studies indicate that Finnish firms use methods of direct participation to a greater extent than do European firms on average or U.S. firms (Poutsma et al. 2006; Jones et al. 2008b), and are probably comparable to countries that are regarded as leaders in this respect, such as other Scandinavian countries (Payne and Keep 2003) or East Asian countries (Kato et al. 2005). It is difficult to say how this would influence the expected relationship between direct participation and financial participation. 


\section{Data and descriptive statistics}

\section{Data source}

The analysis in this paper is based on a new data set the authors collected during December 2005 - January 2006. Our sample was drawn from the Enterprise Register maintained by Statistics Finland. The population of firms targeted was all 1,054 Finnish manufacturing firms having over 50 employees in 2005 . We concentrate on companies that have shares and report their income statements. ${ }^{9} 832$ of these firms were randomly selected and contacted by a phone interviewer. We got usable responses from 398 respondents. This represents $38 \%$ of the total population and $48 \%$ of targeted companies. The characteristics of the sample companies turned out to be very similar to the population in terms of size and industry distributions (see Jones et al. 2008a for details).

The survey covered a large number of questions in various areas. The main areas were basic information on firms (such as size), employee financial participation and performance-related pay (PRP), employee involvement, various management strategies (both HRM and other), training, the use of ICT, and firm ownership and reorganization. The respondents to the survey were managers in charge of the human resource management practices. While in larger companies the respondent was usually the HRM manager, in smaller companies the respondent was usually the CEO. The questions were addressed to the firm at large, rather than individual establishments. ${ }^{10}$

\footnotetext{
${ }^{9}$ In the context of financial participation, a focus on companies, rather than establishments, can be justified because establishments that do not have shares or do not report their profits cannot have their own financial participation schemes.

${ }^{10}$ Compared to other countries, including the US, the incidence of huge firms with business units that have autonomy over some FP schemes is relatively rare. Hence, arguably the use of firm- (rather then establishment) level data is subject to far fewer measurement issues than might emerge in studies based on firm-level data elsewhere.
} 
We start the description of our data by analysing the incidence and changes in financial participation schemes between $2002-2005$. For the sake of consistency, we report descriptive statistics only for those observations that are used in the final regression analyses. Since there are often missing values for variables of interest we have to discard data from 61 companies; thus we are left with a sample 338 companies $(85 \%$ of the original sample). Essentially a similar picture would emerge if we were to use the entire data set to the extent it would be possible.

\section{Financial participation practices}

We start our investigation by looking at PRP schemes. 58\% of our respondents indicate that they had PRP schemes in place in 2002; by 2005, this had increased to $67 \%$. Both of these numbers are very consistent with the figures reported by the Confederation of Finnish Industries (EK 2006). To determine how many PRP schemes can also be regarded as financial participation we utilize two pieces of information that we had collected. First, we asked for "participation rates' (the proportion of workers covered by FP) for both white-collar and blue-collar employees separately for 2002 and 2005. If at least $50 \%$ of employees in both groups were included, then the criterion of "broad-based PRP" was fulfilled; if $100 \%$ of both groups were included, then the PRP system was labeled as "all-inclusive PRP”. Panel A in Table 1 gives the frequencies for each category. It appears that in 2002 around $70 \%$ of all PRP schemes were broad-based, and around $60 \%$ of them were all inclusive. The respective numbers for 2005 were $69 \%$ broad-based PRP schemes, and 63\% all-inclusive PRP schemes. The mean participation rates for both white-collar and blue-collar employees in 2002 were $79 \%$; the participation rates for both groups were $80 \%$ in 2005 . These numbers show that the share of inclusive 
plans and participation rates are, on average at least, very stable over time. Moreover, this evidence shows that most of the Finnish PRP schemes are broad-based in the sense that they include the majority of employees from both employee categories, and indeed most of them include all employees.

Our other criterion for financial participation is that profitability must be among the performance criteria for PRP for both groups of employees. Panel B of Table 1 shows the distribution of performance criteria. It appears that for white-collar employees, profitability is almost always among the criterion for PRP. For blue-collar employees, it is among the performance criteria in $79 \%$ of cases. It is also clear from Panel B that often companies combine other types of performance criteria, especially productivity and product quality, alongside with profitability.

Panel C then shows that, in 2005, 131 respondents had a PRP scheme in place that can be regarded as financial participation (being both broad-based and including profitability as criterion for performance-pay). Following the typology of Poutsma and de Nijs (2003), we call this as cash-based profit-sharing (CPS). Firms with CPS schemes account for almost $40 \%$ of all observations and almost $60 \%$ of observations with any PRP scheme.

\section{TABLE 1 AROUND HERE}

CPS schemes are only one part of the several different forms of financial existing in Finland. As discussed earlier, other types of financial participation include personnel funds, broad-based stock options, and broad-based share ownership. Personnel funds clearly meet the criteria of financial participation, because they are always all-inclusive and the payments to the funds depend on profitability. 18 firms $(5 \%)$ of our sample had 
personnel funds in 2005. Stock option and share ownership schemes can be classified as financial participation if they include a majority of employees. Share ownership by managers or employees (or both) is very common in our sample. 177 (52\%) firms out of 338 report some managerial or employee ownership in 2005 . However, in most cases this is managerial ownership only, often in the form of a company owned solely by an ownermanager. In 82 cases, one or more managers own the majority of the shares in the company. Broad employee ownership (in these sense of over $50 \%$ of employees owning shares) is found in only six firms. Stock options are relatively rare in our data, only around 32 firms (9\%) having them. ${ }^{11}$ Broad-based stock options are even rarer than broad-based share ownership in our sample: only four companies have them. Altogether, 27 firms (8\%) of firms in our sample have some form of financial participation other than a CPS scheme. Thus, other forms of financial participation, when measured by the number of companies, are quantitatively much less important than are CPS schemes. However, in terms of coverage of employees (rather than firms), personnel funds are somewhat more important than they appear in the light of these numbers, because they have been adopted by relatively large companies and they are all-inclusive.

Not only are stock options, share ownership and personnel funds used in a smaller number of firms than broad-based PRP, but they exhibit quite different dynamics. Table 2 shows the dynamics of different types of financial participation schemes between 2002 and 2005. For 2002 since we know only participation rates the definition of broad-based PRP is somewhat less restrictive than what was used for 2005. However, from this table

${ }^{11}$ This is of course much less than in Jones et al. (2006), but the difference is that they concentrated on listed firms, whereas our data includes mostly privately held firms, and stock options are much more common in listed firms. 
it is clear that while the PRP schemes have grown rapidly over the period 2002-2005, other forms of financial participation have stagnated or even declined.

\section{TABLE 2 AROUND HERE}

Our survey data suggest that, compared to many developed economies, Finland ranks relatively high in the use of financial participation, especially regarding cash-based profit-sharing, although less so regarding share-based schemes. Cross-country comparisons are difficult because different studies use markedly different methodologies ${ }^{12}$, but some broad-brush comparisons can be made. In Europe, the leader of profit-sharing is France where profit-sharing schemes are mandatory for companies that have over 50 employees (Perotin and Robinson 2003), but among remaining countries, Finland comes close to the top. In a study of listed companies from four countries that have unusually high incidences of profit-sharing (Finland, Germany, Netherlands, and the UK), Finland had the highest share of broad-based profit-sharing, but the lowest share of broad-based share schemes (Poutsma et al. 2006). Our results are consistent with that study. In the UK, a study based on the 2004 Workplace Employment Relations Survey finds that $34 \%$ of companies have a company- or establishment-level PRP scheme and 20\% of companies have a share scheme (Bryson and Freeman 2010). Compared with those data, Finnish companies seem to have a larger percentage of profitsharing and a lower percentage of share-based schemes. For the U.S., Kruse et al. (2010) report the incidence of financial participation based on GSS data from 2002-2006, which is individual rather than company data. They find that around $36 \%$ of private sector employees are covered by profit-sharing, $19 \%$ by share ownership and $11 \%$ by stock

\footnotetext{
${ }^{12}$ Recall also that our survey is restricted to manufacturing while other surveys sometimes cover a broader range of industries.
} 
options. While the unit of measurement is different in their study, these numbers suggest that profit-sharing is less widespread in the U.S. than in Finland, but share schemes are much more widespread. The higher incidence of share schemes in the U.S. and in the U.K. compared to Finland is not surprising, given that the institutional support (e.g. in the form of tax breaks) is much higher in the U.S. and the U.K. than in Finland. Turning to Japan and Korea, the bonus payment system, which covers nearly all employees (including not only white-collar but also blue-collar workers), has attracted considerable attention and controversy, in particular the claim (e.g. Freeman and Weitzman, 1987) that it is a form of a profit sharing plan. However, more recent studies (Kato, et. al., 2010 and Kato and Morishima, 2003) report that the bonus payment system, with a formal contract stipulating the presence of the profit-sharing plan, is less extensive and is used by one in four to one in three publicly traded firms in these East Asian countries. Though these numbers ought to be considered lower bounds for the incidence of profit sharing in Japan and Korea, the incidence of profit sharing in Finland is still impressive when compared to Japan and Korea. In contrast, share schemes are far more widely used in Japan than in Finland. Close to 80 percent of all firms listed in Tokyo Stock Exchange have employee stock ownership plans with employee participation rates of 50 percent in 2006 (Kambayashi and Kato, 2010). As such the incidence of ESOPs for firms listed on Japanese stock markets has grown from 61\% in 1973 (Jones and Kato, 1995). For companies in general, Jones and Kato (1995) report that only $18 \%$ of all firms (including both listed and unlisted) had an ESOP in 1964 but that this had increased to about $60 \%$ by 1985 . More recent figures on the incidence of share schemes in Japanese or Korean unlisted companies are not available. 
Descriptive statistics

Descriptive statistics for 2005 are given in Table 3 . We see that $43 \%$ of survey firms have a financial participation scheme in place. In the analysis, we further divide them into cash-based profit-sharing (39\%) and other forms of financial participation (8\%), including personnel funds, broad-based stock options and broad-based share ownership.

Among the independent variables, the size of employment has been included in numerous studies, but the results have been found to be very inconsistent (Perotin and Robinson 2003). Mean employment in our sample is 313 employees. There is practically no variation in union presence, since, characteristically for the Finnish industrial relations system, almost all companies have shop stewards. Therefore, our preferred measure of unionization is union density (the percentage of employees belonging to a trade union). Mean union density is $83 \%$.

For employee involvement variables, consistent with Poutsma et al. (2006), we make a distinction between indirect and direct participation. One of the measures we use is the percentage of non-managerial employees on the board of directors. Around $9 \%$ of survey companies have at least one employee representative on the board. In most cases this is a minority representation, but there are four companies where employees have at least $50 \%$ of the seats. We measure employee board representation as a continuous variable, the mean of which is $3 \%$. The other measure of indirect representation is the presence of joint consultation committees (JCC), which are present in $74 \%$ of companies. 
For direct participation items, we construct an index. In this we use similar items to Chi et al. (2007), although we exclude the indirect participation items referred to earlier (board representations and JCC). The items included in this index are presence of self-managed teams, quality circles, job rotation, suggestion scheme, job satisfaction survey, and total quality management. As shown in Jones et al. (2008b), the most common of these practices are job rotation and satisfaction surveys (in over $80 \%$ of companies), and the least common are total quality management (41\%) and self-managed teams $(37 \%)$. The individual practices are assigned the value 1 of present ( 0 otherwise) and the index is calculated by summing the components. The index varies then between 0 and 6 , and the mean of the index is 3.71 .

Similarly, we calculate an index of "advanced management practices". These include six selection, appraisal and monitoring practices: the presence of formal recruitment practices, development talks, enterprise resource planning (ERP) system, ISO certification, benchmarking, and balanced scorecard. The values of the index range from 0 and 6 , and the mean is 4.17 .

We also include measures for training and computer use. Because virtually all companies in our dataset provide workplace training and certainly all use computers, we use as our measures the percentage of employees participating in workplace training in 2005 and percentage of employees using computers in daily work. The mean of the former is $58 \%$ and the mean of the latter is $56 \%$.

To test hypotheses surrounding different stakeholders, our next group of variables includes the ownership dummy variables. The first is foreign majority owned companies, which constitute $21 \%$ of the sample. Second are companies where the largest owner is 
either the state or co-operatives. We combine these two categories because they constitute a fairly small minority of all firms, around $5 \%$. There are only four companies in the sample that are owned by co-operatives, so in most of the companies in this category the largest owner is the state. Further, we have a dummy for managerial majority ownership, which constitute a quarter of the sample. Family firms are identified by using the list of members of Finnish Family Firms' Association. 11\% of firms belong to this category. The comparison category is then domestic firms owned by companies or investors, where the dominant owner is none of the previously mentioned categories.

Finally, we include dummy variables for listed companies ( $6 \%$ of the sample) and multi-establishment firms (50\% of the sample).

\section{TABLE 3 AROUND HERE}

\section{Empirical results}

In this section we present the results (Table 4) from probit models where we evaluate the determinants of financial participation. In column 1, we present the results from the analysis, where the dependent variable is whether any type of financial participation scheme exists or not. In the adjacent columns, we present the results disaggregated according to the type of financial participation. In column 2, we look at the determinants of the commonest plan, namely cash-based profit-sharing. In column 3 we look at the determinants of all other plans. While it might be interesting to look separately at the determinants of share-based schemes (including both stock option and share ownership schemes) on the one hand and personnel funds on the other, we do not present such analysis here, because of the low number of schemes falling in to these categories. 
The coefficients reported in the table are marginal effects, or changes in predicted probabilities when the independent variable changes by one unit. The change in independent variables are discrete changes from zero to one for dummy variables, and one-unit changes for continuous variables. We have used heteroskedasticity-robust standard errors in calculating the z-values. All specifications include 3 age group dummies, 6 industry dummies and 9 region dummies though these are not reported in Table 4

Starting from column 1 of Table 1, we observe that there are significant coefficients among both the corporate governance variables and the industrial relations variables. In addition, the control for company size (log of number of employees) has a positive and statistically significant coefficient. One coefficient that particularly stands out is for stakeholder ownership. If the firm is partially owned by the state or cooperatives, the likelihood of observing financial participation increases by an estimated 52 percentage points. For firms not in stakeholder ownership the estimated probability of observing financial participation is $39 \%$, whereas the same probability for a firm in stakeholder ownership is $91 \%$. This is the only coefficient that is significant at the $1 \%$ level in column 1. Managerial ownership is significant at the $10 \%$ level. If the company is majority owned by its management, the probability of observing financial participation falls by 15 percentage points. Most of the industrial relations variables are statistically insignificant, including union density, employee board representation, joint committees, direct participation, or advanced management practices. However, we find that workplace training is positively and significantly associated with financial participation. An increase in the percent of employees trained by 10 percentage points is associated with roughly a 2 
percentage point increase in observing financial participation. Also computer use is positively and significantly associated with financial participation. A 10 percentage point increase in employees using computers in their daily work increases the likelihood of observing financial participation by 2.5 percentage points. Finally, we observe that the controls for publicly listed status or having multiple establishments are insignificant.

\section{TABLE 4 AROUND HERE}

In column two we present the results for cash-based profit-sharing. The results are very similar to the results presented in column 1 . The coefficient for stakeholder ownership is again large and statistically significant at the $1 \%$ level. Any firm that is classified as being stakeholder owned is associated with a 40 percentage point increase in the likelihood of our observing the existence of a financial participation scheme. Other coefficients are fairly similar, though managerial ownership and firm size are no longer significant. Workforce training and computer use retain the positive coefficients and are significant at the $10 \%$ level.

In column 3 we report results for all other forms of financial participation schemes besides cash based profit sharing. The dependent variable has a value of 1 if the company has any of the following schemes: broad-based stock options, broad-based share ownership, or personnel funds. Some of the results echo those found for the probit findings reported in columns 1 and 2, including a large positive coefficient for stakeholder ownership and a negative coefficient for managerial ownership, but there are also a couple of results that differ from those previously reported. In this specification the coefficient for union density is negative and significant. This may be surprising given that we expected that there would be a positive relationship between unionization and 
personnel funds, which is the commonest form of financial participation in this category. By further probing of this result we find that firms with and without personnel funds have the same degree of unionization, whereas firms with broad-based stock options have somewhat lower union density and especially firms with broad-based share ownership have much lower rates of union density than those without those schemes. We also find that board representation is positively associated with financial participation. This is mostly due to personnel funds: of firms with personnel funds, one in four has employee board representation, whereas the ratio for the rest of the firms is one in ten. Finally, we find that listed status is positively related to these forms of financial participation, especially with stock options and personnel funds.

\section{Conclusions}

In this paper, we have provided the first thorough overview of the nature and determinants of financial participation schemes in Finnish manufacturing companies. Financial participation is found to be quite extensive in Finland--altogether $43 \%$ of companies have at least one financial participation scheme. PRP schemes are especially prevalent and of particular interest. We show that most of these schemes can be regarded as financial participation in the sense that they are broad-based, including the majority of the workforce, and the payments depend at least partly on profitability. This is by far the largest category of financial participation in Finland. Using representative data for Finnish manufacturing companies having 50 or more employees in 2005, this kind of cash-based profit-sharing scheme exists in around $40 \%$ of companies. Other forms of financial participation, including personnel funds, broad-based share ownership, and 
broad-based stock options, are much rarer, and only $8 \%$ of sample companies have them. The dynamics of these two types of schemes are also quite different. When we look at data between 2002 and 2005, we find that many companies adopt cash-based schemes, whereas the number of other financial participation schemes does not increase.

When we look at the determinants of financial participation, one result that stands out clearly is that financial participation schemes are much more common in firms that have stakeholder ownership in the sense that the Finnish state or co-operative organizations are the largest owners of these companies. The difference is strongly significant: $90 \%$ of companies in stakeholder ownership have at least one form of financial participation, whereas only around $40 \%$ of other companies have financial participation. To our knowledge this result is quite novel. One explanation for this finding is that, consistent with the theoretical arguments of Blair (1995) and Levine (1995), profit-maximizing firms may not adopt financial participation because of the short-term pressures they face from the shareholders. Stakeholders, such as the state or co-operatives, are more patient owners, and perhaps therefore they are also likely to cater to the interests of non-controlling stakeholders. It may also be that employees have stronger bargaining power in companies that have a broader mission than simply profit maximization. We also find evidence that financial participation schemes are negatively related to management ownership, which may indicate that managers are reluctant to dilute their return rights.

This result may appear contradictory to the argument that the increase in financial participation at the national level may be due to more emphasis on shareholder value (Poutsma and de Nijs 2003). However, our micro-level findings may not be incompatible 
with the macro-level explanation. For instance, it is possible that the focus on shareholder value has increased the propensity of stakeholder-oriented firms to adopt financial participation schemes, in order to provide for a better alignment of objectives. We should also note that companies where the state or co-operatives are the dominant shareholders are a minority among Finnish manufacturing firms, so there must be other factors explaining the prevalence of financial participation in Finland.

Our remaining results indicate some degree of complementarities, especially with workplace training and computerization of work. We find evidence that some forms of financial participation, especially personnel funds, are more common in the presence of employee board representation, whereas share-based schemes are more common when union density is relatively low. Remarkably, there is no relationship between financial participation and direct participation.

The main implication of our findings is to point to the potential role of variables that have tended to be neglected in single country large scale firm-level surveys of FP. In helping to account for variation in the incidence of different types of FP, we find that corporate governance variables may have a strong influence. To determine whether this is a general result (rather then a finding that occurs on a more restricted basis) the importance we have found for stakeholder variables needs to be examined using survey data for other countries. 
Table 1. PRP and financial participation

Panel A: The incidence of PRP schemes in 2002 and 2005 (N=338)

\begin{tabular}{|l|l|l|l|}
\hline & Yes & No & NA \\
\hline PRP, 2002 & 191 & 138 & 9 \\
& $(58.1 \%)$ & $(31.9 \%)$ & \\
\hline PRP, 2005 & 226 & 112 & \\
& $(66.9 \%)$ & $(33.1 \%)$ & \\
\hline Broad PRP, 2002 & 133 & 196 & 9 \\
& $(40.4 \%)$ & $(59.6 \%)$ & \\
\hline Broad PRP, 2005 & 155 & 183 & \\
& $(45.9 \%)$ & $(54.4 \%)$ & \\
\hline All-inclusive PRP, & 115 & 214 & 9 \\
2002 & $(35.1 \%)$ & $(64.9 \%)$ & \\
\hline $\begin{array}{l}\text { All-inclusive PRP, } \\
2005\end{array}$ & 142 & 196 & \\
\hline
\end{tabular}

Panel B: The criterion for PRP in 2005 (\%)

\begin{tabular}{|l|l|l|}
\hline & $\begin{array}{l}\text { White collar } \\
(\mathrm{N}=211)\end{array}$ & $\begin{array}{l}\text { Blue collar } \\
(\mathrm{N}=189)\end{array}$ \\
\hline Profitability & $96.7 \%$ & $79.4 \%$ \\
\hline Productivity & $53.8 \%$ & $68.9 \%$ \\
\hline Cost savings & $34.3 \%$ & $32.8 \%$ \\
\hline Sales & $31.9 \%$ & $20.9 \%$ \\
\hline Value added & $10.5 \%$ & $16.7 \%$ \\
\hline Customer service & $30.0 \%$ & $23.7 \%$ \\
\hline Product quality & $41.4 \%$ & $55.9 \%$ \\
\hline $\begin{array}{l}\text { Individual development } \\
\text { goals }\end{array}$ & $35.7 \%$ & $15.1 \%$ \\
\hline
\end{tabular}

Panel C: The incidence of cash-based profit-sharing in $2005(\mathrm{~N}=338)$

\begin{tabular}{|l|l|}
\hline Number of firms with cash-based profit- & 131 \\
sharing (CPS) scheme (\%) & $(38.8 \%)$ \\
\hline Number of firms with other type of PRP & 95 \\
scheme & $(28.1 \%)$ \\
\hline Number of firms without a PRP scheme & 112 \\
& $(33.1 \%)$ \\
\hline
\end{tabular}


Table 2: Dynamics of financial participation

\begin{tabular}{|l|l|l|l|l|}
\hline & \# in 2002 & $\begin{array}{l}\text { Adopted 2002- } \\
2005\end{array}$ & $\begin{array}{l}\text { Terminated } \\
2002-2005\end{array}$ & \# in 2005 \\
\hline $\begin{array}{l}\text { Broad-based } \\
\text { PRP }\end{array}$ & 133 & 22 & 6 & 149 \\
\hline $\begin{array}{l}\text { Share } \\
\text { ownership }\end{array}$ & 7 & 0 & 1 & 6 \\
\hline Stock options & 5 & 0 & 1 & 4 \\
\hline Personnel funds & 20 & 5 & 7 & 18 \\
\hline
\end{tabular}

Note: The definition of broad-based PRP is less restrictive than in Panel C of Table 1, because for 2002, we are able to take only participation rates into account, but cannot verify whether profitability was among the criteria for PRP. In this table we only count those schemes for which we have information for 2002, therefore the numbers for 2005 are lower than in Panel A of Table 1.

Table 3: Summary statistics: means and standard deviations

\begin{tabular}{|l|l|l|}
\hline Variable & Mean & Standard deviation \\
\hline Financial participation & 0.43 & 0.50 \\
\hline Cash-based profit-sharing & 0.39 & 0.49 \\
\hline Other financial participation & 0.08 & 0.27 \\
\hline Employment & 313 & 980 \\
\hline Log of employment & 4.98 & 0.99 \\
\hline Union density & 83.46 & 16.10 \\
\hline $\begin{array}{l}\text { Percentage of employees in } \\
\text { board }\end{array}$ & 3.07 & 10.26 \\
\hline $\begin{array}{l}\text { Presence of joint } \\
\text { consultation committee }\end{array}$ & 0.74 & 0.44 \\
\hline Direct participation index & 3.71 & 1.39 \\
\hline $\begin{array}{l}\text { Advanced management } \\
\text { practices index }\end{array}$ & 4.17 & 1.44 \\
\hline $\begin{array}{l}\text { Percentage of workforce } \\
\text { trained }\end{array}$ & 58.42 & 34.87 \\
\hline $\begin{array}{l}\text { Percentage of workforce } \\
\text { using IT daily }\end{array}$ & 56.46 & 29.78 \\
\hline Foreign majority owner & 0.21 & 0.41 \\
\hline State or co-operative owner & 0.05 & 0.22 \\
\hline $\begin{array}{l}\text { Managerial majority } \\
\text { ownership }\end{array}$ & 0.24 & 0.43 \\
\hline Family firm & 0.11 & 0.31 \\
\hline Listed company & 0.06 & 0.24 \\
\hline Multi-establishment & 0.50 & 0.50 \\
\hline
\end{tabular}


Table 4: The determinants of financial participation: probit marginal effects

\begin{tabular}{|c|c|c|c|}
\hline $\begin{array}{l}\text { Independent } \\
\text { variables }\end{array}$ & $\begin{array}{l}\text { Financial } \\
\text { participation (all) }\end{array}$ & $\begin{array}{l}\text { Cash-based profit- } \\
\text { sharing }\end{array}$ & $\begin{array}{l}\text { Other financial } \\
\text { participation }\end{array}$ \\
\hline Log of employees & $\begin{array}{l}0.10^{* *} \\
(2.35)\end{array}$ & $\begin{array}{l}0.061 \\
(1.60)\end{array}$ & $\begin{array}{l}0.010 \\
(0.91)\end{array}$ \\
\hline Union density & $\begin{array}{l}-0.0005 \\
(-0.27)\end{array}$ & $\begin{array}{l}0.0008 \\
(0.41)\end{array}$ & $\begin{array}{l}-0.0012 * * * \\
(-3.19)\end{array}$ \\
\hline Employees in board & $\begin{array}{l}0.0032 \\
(1.07) \\
\end{array}$ & $\begin{array}{l}0.0022 \\
(0.79)\end{array}$ & $\begin{array}{l}0.0016^{* *} \\
(2.22)\end{array}$ \\
\hline $\begin{array}{l}\text { Joint consultation } \\
\text { committee }\end{array}$ & $\begin{array}{l}-0.058 \\
(-0.77)\end{array}$ & $\begin{array}{l}-0.020 \\
(-0.27)\end{array}$ & $\begin{array}{l}-0.0002 \\
(-0.01)\end{array}$ \\
\hline $\begin{array}{l}\text { Direct participation } \\
\text { index }\end{array}$ & $\begin{array}{l}0.010 \\
(0.40)\end{array}$ & $\begin{array}{l}0.022 \\
(0.91)\end{array}$ & $\begin{array}{l}-0.0029 \\
(-0.40)\end{array}$ \\
\hline $\begin{array}{l}\text { Advanced } \\
\text { management } \\
\text { practices index }\end{array}$ & $\begin{array}{l}0.042 \\
(1.52)\end{array}$ & $\begin{array}{l}0.043 \\
(1.64)\end{array}$ & $\begin{array}{l}0.0003 \\
(0.05)\end{array}$ \\
\hline Workforce training & $\begin{array}{l}0.0017^{*} \\
(0.0009)\end{array}$ & $\begin{array}{l}0.0015^{*} \\
(1.76)\end{array}$ & $\begin{array}{l}0.0003 \\
(1.16)\end{array}$ \\
\hline Computer use & $\begin{array}{l}0.0024^{* *} \\
(2.14)\end{array}$ & $\begin{array}{l}0.0019^{*} \\
(1.83)\end{array}$ & $\begin{array}{l}0.0000 \\
(0.15)\end{array}$ \\
\hline $\begin{array}{l}\text { Foreign majority } \\
\text { owner }\end{array}$ & $\begin{array}{l}-0.088 \\
(-1.09)\end{array}$ & $\begin{array}{l}-0.084 \\
(-1.11)\end{array}$ & $\begin{array}{l}0.017 \\
(0.68)\end{array}$ \\
\hline $\begin{array}{l}\text { Stakeholder } \\
\text { ownership }\end{array}$ & $\begin{array}{l}0.524 * * * \\
(3.20)\end{array}$ & $\begin{array}{l}0.396 * * * \\
(2.82)\end{array}$ & $\begin{array}{l}0.286^{* * * *} \\
(3.76)\end{array}$ \\
\hline $\begin{array}{l}\text { Managerial } \\
\text { ownership }\end{array}$ & $\begin{array}{l}-0.148^{*} \\
(-1.94)\end{array}$ & $\begin{array}{l}-0.105 \\
(-1.41)\end{array}$ & $\begin{array}{l}-0.041 * \\
(-1.88)\end{array}$ \\
\hline Family firm & $\begin{array}{l}-0.068 \\
(-0.67) \\
\end{array}$ & $\begin{array}{l}-0.027 \\
(-0.28)\end{array}$ & $\begin{array}{l}0.037 \\
(1.04)\end{array}$ \\
\hline Listed & $\begin{array}{l}0.138 \\
(0.94)\end{array}$ & $\begin{array}{l}0.023 \\
(0.17)\end{array}$ & $\begin{array}{l}0.149^{* *} \\
(2.23)\end{array}$ \\
\hline Multi-establishment & $\begin{array}{l}-0.013 \\
(-0.20)\end{array}$ & $\begin{array}{l}-0.016 \\
(-0.25)\end{array}$ & $\begin{array}{l}-0.022 \\
(-1.27)\end{array}$ \\
\hline Baseline probability & 0.423 & 0.365 & 0.033 \\
\hline Wald Chi2 & $93.61 * * *$ & $78.07 * * *$ & $73.32 * * *$ \\
\hline Pseudo R2 & 0.204 & 0.163 & 0.270 \\
\hline
\end{tabular}

Notes: 1) The table gives marginal effects on probability of observing a financial participation scheme and associated z-values in parenthesis. The change for independent variables is discrete changes from 0 to 1 for dummy variables and one-unit change for continuous variables. The baseline probabilities are evaluated at the mean. The z-values are evaluated by keeping all variables at their mean.

2) Significance levels: * $10 \%$; * $5 \%$; *** $1 \%$.

3) Z-values are calculated by using heteroskedasticity-robust standard errors.

4) All specifications include 3 age group dummies, 6 industry dummies and 9 region dummies that are not reported in the table.

5) The number of observations is always 338 . 


\section{References}

Appelbaum, Eileen, Thomas Bailey, Peter Berg, and Arne L. Kalleberg. 2000.

Manufacturing Advantage: Why High-Performance Work Systems Pay Off. Ithaca, NY:

ILR Press.

Becker, Brian and Barry Gerhart. 1996. "The Impact of Human Resource Management on Organizational Performance: Progress and Prospects." Academy of Management Journal 39 (4):779-801.

Ben-Ner, Avner, W.Allen Burns, Gregory K. Dow and Louis Putterman (2000):

'Employee Ownership: An Empirical Exploration', in Margaret M. Blair and Thomas A. Kochan (eds.): The New Relationship: Human Capital in the American Corporation, Washington D.C.: Brookings, 194-232.

Ben-Ner, A. and D. Jones (1995) 'Employee Participation, Ownership and Productivity: A Theoretical Framework', Industrial Relations 34: 532-555.

Blair, Margaret (1995): Ownership and Control: Rethinking Corporate Governance for the Twenty-First Century, Washington, D.C.: Brookings.

Bloom, Nicholas and John van Reenen (2007): 'Measuring and Explaining Management Practices Across Firms and Countries', Quarterly Journal of Economics 122 (4): 1351408.

Böckerman, Petri and Roope Uusitalo (2006):'Erosion of the Ghent System and Union Membership Decline: Evidence from Finland." British Journal of Industrial Relations 44 (2):283-303.

Bresnahan, Timothy F., Erik Brynjolfsson, and Lorin M. Hitt. 2002. "Information Technology, Workplace Organization, and the Demand for Skilled Labor: FirmLevel Evidence," Quarterly Journal of Economics, 117(1): 339-376.

Bryson, Alex and Richard Freeman (2010) "How Does Shared Capitalism Affect Economic Performance in the United Kingdom?", in Douglas L. Kruse, Richard B. Freeman and Joseph R. Blasi (eds.) Shared Capitalism at Work: Employee Ownership, Profit and Gain Sharing, and Broad-based Stock Options , University of Chicago Press and NBER, 201-24.

Chi, Wei, Richard B. Freeman and Morris M. Kleiner. 2007. "Adoption and Termination of Employee Involvement Programs,” NBER working paper 12878.

EK (2006): 'Tulospalkkaus yksityisellä sektorilla: EK:n palkkausjärjestelmätiedustelu 2005” Helsinki: The Confederation of Finnish Industries. 
Estrin, Saul, Jan Hanousek, Evzen Kocenda and Jan Svejnar (2009): "Effects of Privatization and Ownership in Transition Economies", Journal of Economic Literature 47 (3): 699-728.

Festing, Marion, Yvonne Groening, Rüdiger Pabst and Wolfgang Weber (1999) 'Financial participation in Europe - determinants and outcomes' Economic and Industrial Democracy 20(2): 295-329.

Freeman, Richard B. and Martin L. Weitzman (1987): "Bonuses and Employment in Japan." Journal of the Japanese and International Economies, 1(2), pp. 168-94.

Freeman, Richard, Joseph Blasi and Douglas Kruse (2010): 'Introduction', in Douglas L. Kruse, Richard B. Freeman and Joseph R. Blasi (eds.) Shared Capitalism at Work: Employee Ownership, Profit and Gain Sharing, and Broad-based Stock Options , University of Chicago Press and NBER, 1-37.

Gregg, Paul A. and Stephen J. Machin (1988) 'Unions and the incidence of performance linked pay schemes in Britain' International Journal of Industrial Organisation, 6 (1): 91-109.

Hyytinen, Ari, Iikka Kuosa, and Tuomas Takalo (2003): 'Law or Finance: Evidence From Finland', European Journal of Law and Economics, 16(1): 59-89.

Jones, Derek C. and Panu Kalmi (2009): 'Trust, Inequality and the Size of the Cooperative Sector: Cross-Country Evidence', Annals of Public and Co-operative Economics 80(2): 165-95.

Jones, Derek C., Panu Kalmi, Takao Kato and Mikko Mäkinen (2008a): 'The Effects of Human Resource Management Practices on Firm Performance: Preliminary Evidence from Finland', Discussion Paper 1121, The Research Institute for the Finnish Economy.

Jones, Derek C., Panu Kalmi, Takao Kato and Mikko Mäkinen (2008b): 'The Incidence and Determinants of Employee Involvement - Evidence from the Finnish Manufacturing Sector', Discussion Paper 1131, The Research Institute for the Finnish Economy.

Jones, Derek C., Panu Kalmi and Mikko Mäkinen. 2006. "The Determinants of Stock Option Compensation: Evidence from Finland" Industrial Relations 45 (3): 437 - 468.

Jones, Derek C., Panu Kalmi and Mikko Mäkinen (2010): 'The Productivity Effects of Stock Option Schemes: Evidence from Finnish Panel Data', Journal of Productivity Analysis 33 (1): 67-80

Jones, Derek C. and Takao Kato (1993): 'The Scope, Nature, and Effects of Employee Stock Ownership Plans in Japan', Industrial and Labor Relations Review, 46(2): 352-67. 
Jones, Derek C. and Takao Kato (1995). "The Productivity Effects of Employee StockOwnership Plans and Bonuses: Evidence from Japanese Panel Data." American Economic Review, 85(3), pp. 391-414.

Jones, Derek C. and Jeffrey Pliskin (1997): 'Determinants of the Incidence of Group Incentives: Evidence from Canada', Canadian Journal of Economics, 30 (4b): 1028-45.

Kalmi, Panu (2005): 'Finland', unpublished inventory study for the project 'Changes in the Patterns of Financial Participation in Europe', Radboud University.

Kalmi, Panu and Antti Kauhanen (2008): 'Workplace Innovations and Employee Outcomes: Evidence from Finland', Industrial Relations 47(3): 430-59.

Kalmi, Panu and Christina Sweins (2010): 'The Performance Effects of Profit-Sharing: Subjective and Objective Measures Compared', forthcoming in Tor Eriksson (ed.)., Advances in the Economic Analysis of Participatory and Labor-Managed Firms, vol. 11. Emerald.

Kambayashi, Ryo and Takao Kato (2010): "The Japanese Employment System after the Bubble Burst: New Evidence," forthcoming in K. Hamada, A. Kashyap, M. Kuroda and D. Weinstein, Japan's Bubble, Deflation, and Stagnation MIT Press,.

Kato, Takao, Ju Ho Lee, Kang-Sung Lee and Jang-Soo Ryu (2005): 'Employee Participation and Involvement in Korea: Evidence from a New Survey and Field Research', International Economic Journal, 19 (2): 251-81.

Kato, Takao, Ju Ho Lee and Jang-Soo Ryu (2010). "The Productivity Effects of Profit Sharing, Employee Ownership, Stock Option, and Team Incentives: Evidence from Korean Panel Data," forthcoming in Tor Eriksson, Advances in the Economic Analysis of Participatory and Labor-Managed Firms, vol. 11. Emerald.

Kato, Takao and Motohiro Morishima (2003): 'The Nature, Scope and Effects of Profit Sharing in Japan: Evidence from New Survey Data', International Journal of Human Resource Management 14(6): 942-55.

Kauhanen, Antti (2009): "The Determinants of Incidence of Workplace Innovations: Evidence from an Employee Survey." Economic and Industrial Democracy 30(3): 45480.

Kauhanen, Antti and Hannu Piekkola (2006): 'What Makes Performance-Related Pay Schemes Work? Finnish Evidence', Journal of Management and Governance 10(2): 14977.

Kochan, Thomas A., Robert McKersie and John Chalykoff (1986): 'The Effects of Corporate Strategy and Workplace Innovations on Union Representation', Industrial and Labor Relations Review 39(4): 487-501. 
Kruse, Douglas L. (1996): 'Why Do Firms Adopt Profit-Sharing and Employee Ownership Plans?', British Journal of Industrial Relations 34(4): 515-38.

Kruse, Douglas, Joseph Blasi and Rhoekeun Park (2010): 'Shared Capitalism in the U.S. Economy: Prevalence, Characteristics, and Employee Views on Financial Participation in the Enterprises', in Douglas L. Kruse, Richard B. Freeman and Joseph R. Blasi (eds.) Shared Capitalism at Work: Employee Ownership, Profit and Gain Sharing, and Broadbased Stock Options, University of Chicago Press and NBER, 41-75.

Levine, David I. (1995): Reinventing the Workplace: How Business and Employees Can Both Win, Washington, D.C.: Brookings.

Mäkinen, Mikko (2010): Stock option schemes and firm technical inefficiency: evidence from Finland", Forthcoming in Tor Eriksson (ed.) Advances in the Economic Analysis of Participatory and Labor Managed Firms, vol. 11. Emerald.

Payne, Jonathan and Ewart Keep. 2003. "Revisiting the Nordic Approaches to Work Reorganization and Job Redesign: Lessons for U.K. Skills Policy.” Policy Studies 24 (4):205-225.

Pendleton, A. (1997) 'Characteristics of workplaces with financial participation: evidence from the WIRS’ Industrial Relations Journal 28 (2): 103-119.

Pendleton, Andrew (2006): 'Incentives, Monitoring, and Employee Plans: New Evidence and Interpretations', Industrial Relations, 45(4): 753-77.

Pendleton, Andrew, Erik Poutsma, Jos van Ommeren and Chris Brewster (2003). 'The Incidence and Determinants of Employee Share Ownership and Profit Sharing in Europe' in Takao Kato and Jeffrey Pliskin, (eds.), The Determinants of the Incidence and Effects of Participatory Organisations. (Advances of the Economic Analysis of Participatory and Labor Management, Volume 7). Oxford: Elsevier Science ltd..

Pérotin, V. and A. Robinson (2003) Employee Participation of Profit and Ownership: A Review of Issues and Evidence, Luxembourg: European Parliament.

Piekkola, Hannu (2005): 'Performance-Related Pay and Firm Performance in Finland', International Journal of Manpower, 26 (7/8): 619-35.

Poutsma, Erik and Willem de Nijs (2003): 'Broad-based Employee Financial Participation in the European Union', International Journal of Human Resource Management 14(6): 863-92.

Poutsma, Erik and Fred Huijgen (1999). ,European diversity in the use of participation schemes.' Economic and Industrial Democracy, 20 (2): 197-223. 
Poutsma, Erik, Panu Kalmi and Andrew Pendleton 2006: 'The Relationship Between Financial Participation and Other Forms of Participation: New Survey Evidence from Europe', Economic and Industrial Democracy 27(4): 637-67.

Robinson, Andrew M. and Hao Zhang (2005): 'Employee Share Ownership: Safeguarding Investments in Human Capital', British Journal of Industrial Relations 43(3): 469-88.

Schulze, William S., Michael H. Lubatkin, Richard N. Dino and Ann K. Buchholtz (2001): "Agency Relationships in Family Firms: Theory and Evidence", Organization Science 12(2): 99-116.

Shleifer, Andrei and Robert W. Vishny (1997): 'A Survey of Corporate Governance', Journal of Finance, 52(2): 737-83.

Smith, Stephen C. (1988): 'On the Incidence of Profit- and Equity-Sharing: Theory and an Application to the High-Tech Sector', Journal of Economic Behavior and Organization 9(1): 45-58.

Sweins, Christina, Panu Kalmi and Kiisa Hulkko-Nyman (2009): 'Personnel Knowledge of the Pay System, Pay Satisfaction and Pay Effectiveness: Evidence from Finnish Personnel Funds', International Journal of Human Resource Management 20(2): 45777.

Tainio, Risto and Kari Lilja (2003): 'The Finnish Business System in Transition: Outcomes, Actors, and Their Influence', in Barbara Czarniawska and Guije Sevon (eds.): Northern Lights: Organisation Theory in Scandinavia, pp. 69-87, Copenhagen:

Copenhagen Business School Press.

Tirole, Jean (2001): 'Corporate Governance', Econometrica, 69 (1): 1-35. 